\title{
Serial Crime, Serious Threats? Replicating the "Yellow Peril" in British Popular Crime Fiction
}

\author{
Marilena Parlati \\ Dipartimento di Studi Linguistici e Letterari, Università di Padova \\ marilena.parlati@unipd.it \\ $<$ https://unipd.academia.edu/MarilenaParlati>
}

\begin{abstract}
From 1912 and for numerous decades, Sax Rohmer contributed to create, and recreate, an archvillain of tremendous vigour, Fu Manchu, whose routing lives, appallingly magnetic powers, subterranean connections made him a global star. In this paper I peruse this multi-faceted serial icon, formulaic and yet also changing over time, and see its presence and apparent disappearance from the cultural panorama of the Anglophone world. This multimedial serial figure has been let loose, like Frankenstein's creature, and its progeny may still be detected in film, cartoons and global popular culture.
\end{abstract}

\section{Keywords}

Yellow Peril; Sax Rohmer; Fu Manchu; Seriality; Serial 'things'

\section{Sommario/Content}

o. Introduction

1. Serial Stereotypes

2. Stereotype in Seriality

References 


\section{Ocula ${ }^{22}$}

Vol 21, No 22 (April 2020) • DOI: 10.12977/ocula2020-12

Marilena Parlati | Serial Crime, Serious Threats? Replicating the 'Yellow Peril' in British Popular Crime Fiction

\section{o. Introduction}

In this paper I intend to suggest that Western stereotypes on "China" and its inhabitants have taken many shapes and shades over many centuries of encounters and mutual misunderstandings. Racial (and racist) discourse has often come to the rescue of imperialist and paranoid propaganda, which has been triggered and fuelled over time by popular fiction and culture both in Europe and in North America. These have often "figured" Chinamen as devious and smart in their unending ambition of mastering the world, yet paradoxically mollified and unmanned by their fantasmatic opium addiction, and Chinawomen as erotically and powerfully enticing fatal women.

By way of fundamental example, what I wish to introduce, or reintroduce, is specifically one of the most popular cultural icons of the twentieth century. Insidious, indeed, an image phantasmatically floating above the sites of media production, a mutant, a replicant (notwithstanding and due to his exceptionality) and a literal revenant whose figurative power has insisted on global audiences for many decades. And still it does, as I hope to prove.

The texts which feature the archvillain Dr Fu Manchu, their transmedia perambulations, the innumerable translations and adaptations one can detect worldwide have superciliously and monolithically been defined as "racist", as "rubbish" which must be cast away, in its unbearable political incorrectness. Yet, of course, as a remarkable example of "yellowfacing", it has wreaked havoc but also worked miracles as a fantastic machinic repertoire in Europe and across the oceans alike.

In order to peruse the complicated procedures for "Whitening skins and yellowmasking" (cfr. Fanon 1952) that the Devil Doctor has in various ways and through various media come to represent, I shall focus on two main issues both concerned with serialization, or rather seriality, and stereotyping in connection with British (and American) twentieth-century narrative, film, comics, and popular culture intended as a magmatically unstoppable whole; I intend to show how the nondescript entities "China" and "Chinamen" have come to vibrant life - in European and North-American consciousness - via continuous misunderstandings and careful misreadings, specially in the course of the nineteenth century, in particular in regard to the slightly vested interests of the British Empire, eager to open that huge, massive yet crumbling empire to its voracious libidinous commercial desires. My second point reverses the key terms, to face seriality as form, and eventually the form faces and masks take in the narrative sequences and sequels first of the years around 1913, when the first texts featuring him see the light, and later in the cluster of the '3os. Fu Manchu would still remain the shadowy/all-too-visible protagonist of many other texts, until The Emperour Fu Manchu, dating to 1959 and would tell different stories about the stock type, propaganda and imagined communities of a Cold War world. I wish to conclude on an evocative contemporary revision of the "Fu Manchu Complex", which cast an ironical side-look on the visual power of iteration. 


\section{Ocula ${ }^{22}$}

Vol 21, No 22 (April 2020) • DOI: 10.12977/ocula2020-12

Marilena Parlati | Serial Crime, Serious Threats? Replicating the 'Yellow Peril' in British Popular Crime Fiction

\section{Serial Stereotypes}

The Yellow Danger was the title of an 1898 novel by the English detective, occult and sensation fiction writer M.P. Shiel. It conveyed ideas and shaped anxieties related to the presence of Chinese migrant communities within the safe havens of the British homeland. Truly enough, the size of the Limehouse area and the number of its inhabitants were by no means sufficient to justify any reasonable fear of the supposed danger embodied by vicious Chinamen who were both allegedly prone to wasting time and mental energies in opium dens, to pulling otherwise innocent and pure British upper-class ladies towards sexual promiscuity, and yet paradoxically ready not only to infect the British, their women, and the whole Western world but also to infiltrate or swarm all of these with the force of their huge numbers and community ties. Well-known territorialisation and reterritorialization (cfr. Deleuze and Guattari 1980) mechanisms had already started to produce a haunting 'yellow peril' anxiety and paranoid equivocation: as a splendid case of failed encounter, the Middle Kingdom (the central core name, the self-referential entity zhong guo implies in its original ideogrammatic manifestation) was mistaken by modern Europeans and retranslated: thus, by means of a tremendously efficacious synechdoche the Qing dynasty came to signify China, a spatial expanse in lieu of a chronological and political "thing". Edward Said taught us in 1978 to read the ponderous archival effort entailed by the European human and social sciences of the eighteenth and nineteenth centuries as the very foundation of imperialism: yet, his influential definition of Orientalism as «a Western style for dominating, restructuring, and having authority over the Orient» (Said 1978: 3) seems to fail to account for Britain's problematic relations with a politically independent empire that, despite its many economic concessions to the West, largely refused British domination, restructuring, and authority. Furthermore, as many scholars have noted, in Orientalism Said selects his case studies from a literary canon which does not even vaguely envisage popular culture, casually obliterating the pervasive images and hallucinations it has produced.

On the other hand, the modular (cfr. Anderson 1983) Chinatowns that seemed to the British eyes to have invaded its colonies and its own capital city were by many (journalists, politicians, popular writers) taken as clues of the ferocious and silent attempt of Chinese masses intent on insinuating behind the lines of civilized Europe. It comes as no surprise, therefore, that adventure, detective and crime fiction took the lead in assuaging the intoxicated consciences of media audiences and serve them with larger-than-life enemies they could enjoy and defeat at least by proxy, at least ideally and on a temporary iterative basis. In the words of Denson and Mayer,

The serial figure... is not merely a character in a series; rather, it exists as a series - across a variety of media, shaped by a dynamic interplay between repetition and variation. Serial figures such as Batman, Sherlock Holmes, Fu Manchu, Frankenstein's monster, Dracula, or Tarzan proliferate in literary works, films, comics, television se- 


\section{Ocula ${ }^{22}$}

Vol 21, No 22 (April 2020) • DOI: 10.12977/ocula2020-12

Marilena Parlati | Serial Crime, Serious Threats? Replicating the 'Yellow Peril' in British Popular Crime Fiction

ries, and video games, and (in stark contrast to the characters of ongoing, monomedial series) they constitute discontinuous, plurimedial serialities without regard for diegetic consistency. Serial figures are 'flat' in most of their instantiations, and they show a remarkable self-reflexive awareness of the material parameters of their own serial restagings - and the media-technical changes informing these restagings. (Denson and Mayer 2011: np, my italics)

And to one such item of orientalised/orientalising popular culture pivoting on "China" as shadowy nonextant referential marker I do revert.

\section{Stereotype in Seriality}

In 1912, Arthur Ward, alias Sax Rohmer, published the first short story The Zamyat Kiss, which featured the malignant Dr Fu Manchu. A set of other serialized stories followed, and were later collected in 1913 in The Mystery of Fu Manchu. Or Insidious Fu Manchu, the title the novel bore for US and Canadian markets: the restaging discontinuity just suggested started early on in the history of the spread of this fantastic figure. Two other novels were serialized and later published, again with different European and American titles (The Return of Fu Manchu and The Hand of Fu Manchu), in 1916 and 1917. Indeed, for huge numbers of enthusiastic and later affectionate readers, Fu Manchu immediately became the uncannily intimate and distant enemy inhabiting the very wharfs and docks of London. Bernardelli aptly summarizes Umberto Eco's views on "topos characters", programmatically conventional, and thus easy to remember, «less rich in the historical-cultural referential complexity generally attached to a typical narrative character, a topical/topos character can better connect with his reader's archival memory» (Bernardelli 2016: 4, my translation). The evil/devil doctor was one of these topoi, with the following description being used as a microtextual brand recognizable by audiences and readers worldwide.

Imagine a person, tall, lean and feline, high-shouldered, with a brow like Shakespeare and a face like Satan, a close-shaven skull, and long, magnetic eyes of the true cat-green. Invest him with all the cruel cunning of an entire Eastern race, accumulated in one giant intellect, with all the resources of science past and present, with all the resources, if you will, of a wealthy government - which, however, already has denied all knowledge of his existence. Imagine that awful being, and you have a mental picture of Dr. Fu-Manchu, the yellow peril incarnate in one man. (Rohmer 1913: 25-26)

Rohmer's Fu Manchu bears within his own name the predications of all things Chinese for the British. The honourable Manchu, or Qing, was a living revengeful memorial of the traumatic Boxer rebellion, or war, that had stormed China in 1900 and 1901 in its attempt at sweeping foreign "devils" off the country. Endowed with characteristic, stereotypical martial arts skills, the fighting masses that had ravaged the port cities of the Empire had taught the British and other foreigners the signifiying lesson that their ideas on the pas- 


\section{Ocula ${ }^{22}$}

Vol 21, No 22 (April 2020) • DOI: 10.12977/ocula2020-12

Marilena Parlati | Serial Crime, Serious Threats? Replicating the 'Yellow Peril' in British Popular Crime Fiction

sivity and amenability of the Manchu subjects had been all but rooted. Yet, the clear perception that the Manchus as monarchs were in all senses a dying dynasty and that their Empire was on the brink of decay had later been proven by the forced resignation of Emperour Puyi and the attempted modernization policies of Dr Sun Yat Sen, in the outrageous Republic which had substituted a century-old apparatus. As a concoction of traditional and modern powers, always at the forefront of experimental and historical knowledge, Fu Manchu did indeed at the same time incarnate stereotypes and reinscribe them from within, as well as from without, in his phenotypical divergence from the averred, small and effeminate Chinamen popular cultural texts had already spread.

This topos character was much more splintered than one may at first sight acknowledge. In the view of Urmila Seshagiri, in fact,

At a time when so much popular fiction functioned as a transparent, unmediated showcase for imperialist ideology, Rohmer's narratives, albeit unwittingly, expose the limitations of a Western imperial state and its white subjects. In these bestselling thrillers, the discontinuities of race provide a nexus for the broader discontinuities of a modern imperial nation whose global mastery is determined by the acquisition and dissemination of knowledge. When knowledge ceases to be the province and defining characteristic of the West, nether patriotic narrative bluster nor the resources of the patria itself can guarantee a racial victory over Fu-Manchu. (Seshagiri 2006: 186-187)

In this line, magazine seriality in particular permitted, or maybe truly prescribed, the spatial spread of a multimodal archive which provided information in the form of journalistic coverages, advertising campaigns, diagrams, maps and lampoons which coded the world through very different, though coterminous discourses. While in his first textual versions Fu Manchu rarely appears and speaks, being more phantasmatically present in his feared invisibility, a truly two-dimensional fixation was performed by the first film productions. In $1923 \mathrm{Fu}$ Manchu's evil deeds were vehemently marketed with obsessive posters hung in tube stations and streets alike with the Devil's visage pointing to his uncanny ominous overt visibility and networked presence. Thus, the interplay between visibility and invisibility that had marked the discontinuities - in an allegedly formulaic cluster of texts - was left behind in favour of mass-reproduced iconical and fastidious intimacy.

As for the crimes that Fu Manchu commits, or is to commit in the course of the texts, mostly they have to do with appropriating fetish objects, things possessed with magical and iconical powers conferred by the authority of the past. Often it is up to the antagonists Sir Denis Nayland Smith, muscular Christian and celibate, and his medical friend Dr Petrie (an obvious reference to Flinders Petrie the Egyptologist and collector) who, like Watson, is far too prone to be distracted by feminine guiles. In another characteristic move that the novel introduces (and film truly obsessively thrives on), in the Fu Manchu meaning machine femininity is typically erotically potent, exotically enthralling as in the case of Fah Lo Suee, Fu Manchu's daughter, femme fatale and 


\section{Ocula}

Vol 21, No 22 (April 2020) • DOI: 10.12977/ocula2020-12

Marilena Parlati | Serial Crime, Serious Threats? Replicating the 'Yellow Peril' in British Popular Crime Fiction

master villain herself, and even more relevantly of the Arabian slave Karamaneh, later turned into the more "decent" and domesticated Kara Petrie.

Many there are, I doubt not, who will regard the Eastern girl with horror. ... No man having seen her could have condemned her unheard. ... That she valued human life but little was no matter for wonder. Her nationality - her history - furnished adequate excuse for an attitude not condonable in a European equally cultured.

But indeed let me confess that hers was a nature incomprehensible to me in some respects. The soul of Karamaneh was a closed book to my short-sighted Western eyes. But the body of Karamaneh was exquisite; her beauty of a kind that was a key to the most extravagant rhapsodies of Eastern poets. Her eyes held a challenge wholly Oriental in its appeal; her lips, even in repose, were a taunt. And, herein, East is West and West is East. (Rohmer 1913: 254-255, my italics)

By readapting and inverting a famous line from Rudyard Kipling's The Ballad of East and West (1889) Rohmer produces a confusing blurring of topographical and sexual boundaries which fares with great relevance in the first books of the series, set in an already-invaded London between Mayfair and the Docks. In the later resurrections of the Chinese doctor, resilience probably being the Doctor's most heinous crime, Rohmer would devise more transnational, global settings, which range from the Middle East (Iran, Iraq, Afghanistan) to Egypt, New York, South America, a Pacific island, Venice, Paris, and Maoist China. In the 1930s, The Mask of Fu Manchu (1932) was another massive commercial success, due to the complicit looping of series and films. It also marked a transformation in the dissemination of the figure, turning towards a US market (and to Collier's as its preferred publication site) and anxiety-ridden spectators. The self-evident modularity of the topos takes/hides the face of a movie star monster expert such as Boris Karloff (who was in the same years one of the most famous and visibly recognizable Frankenstein creatures ever produced). In this novel (and film) counterfeiting and masking strategies point to another crucial node of signification. Sir Lionel Barton, a careless English archaeologist-cum-gentleman, bluntly bombs a tomb into pieces to discover the legendary scimitar and mask of Genghis Khan (indeed all but a Chinese). Possibly criminal in its own terms, this act triggers the ambition of the Doctor who feverishly attempts to unite "Orientals" under the sign of a gigantic commander and destroyer. In the series and films, things take on life, are copied, stolen, evaluated, displayed: both these and later media routinely play on tracing originals, mocking expertise, and ef-facing authenticity. On the one hand, this perfectly mirrors another stereotype haloing on the "Chinese", who were already perceived as experts in counterfeiting goods, and obviously modular replication and copyright law infringement still seem to be a widely-shared asset in global portrayals of the Red Dragon.

Already in the 1910s Fu Manchu's texts were symptomatic of the "exhibitionary complex» that Tony Bennett (1988) diagnoses as an ideological device of Western paranoid imperialism in its typical obsessions with thing 


\section{Ocula}

Vol 21, No 22 (April 2020) • DOI: 10.12977/ocula2020-12

Marilena Parlati | Serial Crime, Serious Threats? Replicating the 'Yellow Peril' in British Popular Crime Fiction

culture, museums, but also chemical concoctions, hyperbolic electrical tools and primitive freakish zoos and tortures. From the 1930 s on, and later in the 1960 s films starring Christopher Lee, the visual politics of de-facement and the assemblage and reassemblage of faces as objects seem to me to be tantalizingly obsessive narrative techniques adopted by both cinema and novels. For Robert Rushing, «our engagement with classic detective fiction is fundamentally an obsessive-compulsive urge to repeat» (Rushing 2007: 91). Ideologically and politically speaking, masking and unmasking stand at the obsessive-compulsive core of a recent British play by Daniel York Loh, who revisits the storylines, highlights the ideological distortions of the myth and diagnoses what he names the Fu Manchu Complex to mark the centenary of the Doctor's culturally pathological first steps. York reverts the masking procedures of traditional "yellowfacing", choosing "Chinese" actors and having them wear partially white phantom masks which intriguingly help underwrite any assumption concerning oversimplistic identity politics and practices. In fact, the leading role of the evil mastermind was actually played by Chipo Chung, a Zimbabwean-Chinese-British woman. In the hilarous parody which was performed at London Ovalhouse, one can still detect the resilient, or possibly obsessive, pervasive, serial presence of «that awful being... Dr. Fu-Manchu, the yellow peril incarnate in one man» (Rohmer 1913: 26).

When faced by «the dark and secret things of the East, of that mysterious East out of which Fu-Manchu came, of that jungle of noxious things whose miasma had been wafted Westward with the implacable Chinaman» (Rohmer 1916: 65), many white Western European writers seem to have suffered from the obsessive-compulsive drive Rushing deals with when mentioning the urge to repeat he sees at the core of detective fiction. Indeed, as I have intended to suggest, in the replicable yet mutant seriality of the Fu-Manchu figure, paranoid fears have fetched far and wide into the cultural conscious and unconscious of a purportedly univocal Western culture and have thus depicted, filmed, drawn, described China as a non-extant equally univocal entity aporistically stuck both in the middle of its bygone imperial past and of its equally portentuous present and future overarching ambitions.

\section{References}

Anderson, Benedict

1983 Imagined Communities. Reflections on the Origins and Spread of Nationalism, London, Verso.

Bennett, Tony

1988 “The Exhibitionary Complex", New Formations, 4, Spring, pp. 73-102.

Bernardelli, Andrea

2016 "Eco e le forme della narrazione seriale. Alcuni spunti per una discussione", Between, VI, 11, May, pp. 1-11. 


\section{Ocula ${ }^{22}$}

Vol 21, No 22 (April 2020) • DOI: 10.12977/ocula2020-12

Marilena Parlati | Serial Crime, Serious Threats? Replicating the 'Yellow Peril' in British Popular Crime Fiction

Bloom, Clive

1996 "West is East: Nayaland Smith's Sinophobia and Sax Rohmer's Bank Balance", in Cult Fiction. Popular Reading and Pulp Theory, London, Palgrave, pp. 178-191.

Chen, Tina

2002 "Dissecting the 'Devil Doctor': Stereotype and Sensationalism in Sax Rohmer's Fu Manchu”, in Lee, J.; Lim I. L.; Matsukawa, Y. (eds), Re/Collecting Early Asian America. Essays in Cultural History, pp. 218-237.

Deleuze, Gilles; Guattari, Félix

1980 Capitalisme et schizophrénie 2: Mille Plateaux, Paris, Minuit.

Denson, Shane; Mayer, Ruth

2011 "Plurimediality and the Serial Figure", In Media Res, 13 Dec. 2011.

Fanon, Frantz

1952 Peau noire, masques blancs, Paris, Seuil.

Fiske, Shanyn

nd "Modeling Masculinity: Engendering the Yellow Peril in Fu-Manchu and Thomas Burke's Limehouse Nights". <http://www.branchcollective.org/?ps articles=shanyn-fiske-modeling-masculinity-engendering-the-yellow-perilin-fu-manchu-and-thomas-burkes-limehouse-nights $>$. Last accessed 12 June 2019.

Frayling, Christopher

2014 The Yellow Peril. Dr Fu Manchu and the Rise of Chinaphobia, London, Thames \& Hudson.

Hevia, James L.

1998 "The Archive State and the Fear of Pollution from the Opium Wars to Fu Manchu”, Cultural Studies, 12, 2, pp. 234-264.

Mayer, Ruth

2013 Serial Fu Manchu. The Chinese Supervillain and the Spread of Yellow Peril Ideology, Philadelphia, Temple University Press.

Rohmer, Sax

1913 The Insidious Dr. Fu-Manchu: Being a Somewhat Detailed Account of the Amazing Adventures of Nayland Smith in his Trailing of the Sinister Chinaman, New York, Burt.

1913 The Mystery of Fu-Manchu, London, Methuen.

1916 The Return of Dr. Fu-Manchu, New York, McBride.

1916 The Devil Doctor, Hitherto Unpublished Adventures in the Career of the Mysterious Dr. Fu-Manchu, London, Methuen.

1917 The Hand of Fu-Manchu, Being a New Phase in the Activities of Fu-Manchu, the Evil Doctor, New York, Burt.

1917 The Si-Fan Mysteries, London, Methuen.

1932 The Mask of Fu Manchu, Collier's (May-July).

1932 The Mask of Fu Manchu, New York, The Crime Club.

1959 Emperour Fu Manchu, London, Herbert Jenkins.

2012 The Mystery of Dr Fu-Manchu, London, Titan Books.

2013 The Return of Dr. Fu-Manchu, CreateSpace.

2013 The Mask of Fu Manchu, London, Titan Books.

2018 The Hand of Fu Manchu, CreateSpace. 


\section{Ocula ${ }^{22}$}

Vol 21, No 22 (April 2020) • DOI: 10.12977/ocula2020-12

Marilena Parlati | Serial Crime, Serious Threats? Replicating the 'Yellow Peril' in British Popular Crime Fiction

Rushing, Robert A.

2007 Resisting Arrest. Detective Fiction and Popular Culture, Penguin-Random House, Canada.

Said, Edward W.

1978 Orientalism, New York, Pantheon.

Seshagiri, Urmila

2006 "Modernity's (Yellow) Perils: Dr. Fu Manchu and English Race Paranoia", Cultural Critique, 62, Winter, pp. 162-194.

Shiel, M.P.

1898 The Yellow Danger. The Story of the World's Greatest War, London, Grant Richards.

Shih, David

2009 "The Color of Fu Manchu: Orientalist Method in the Novels of Sax Rohmer", The Journal of Popular Culture, 42, 2, pp. 304-317.

York Loh, Daniel

2013 The Fu Manchu Complex, London, Moongate Productions, Ovalhouse.

Marilena Parlati è Professore associato di Letteratura inglese presso l'Università di Padova. I suoi ambiti di ricerca sono le letterature e culture anglofone del 'lungo Ottocento', in particolare in relazione a cose/oggetti, merci e tracce residuali, ma anche alle questioni relative alla costruzione dei ruoli di genere vittoriani; si occupa da tempo anche di letterature contemporanee, studiando temi quali trauma, ecocritica e nuclearità, come pure le molte complessità della corporeità dentro il testo letterario e artistico (su cui è in uscita una monografia). Attualmente è presidente del corso di laurea in Lingue, Letterature e Mediazione culturale dell’Università di Padova. 